\title{
Firmer Roots of Ethnicity and Nationalism? New Historical Research and Its Implications for Political Science
}

\author{
Kurt Weyland (1), University of Texas at Austin \\ kweyland@austin.utexas.edu
}

Germany: A Nation in Its Time: Before, During, and After Nationalism, 1500-2000. By Helmut Walser Smith. New York: Liveright, 2020. 608p. \$39.95 cloth.

From Peoples into Nations: A History of Eastern Europe. By John Connelly. Princeton: Princeton University Press, 2020. 968p. \$35.00 cloth.

$\Lambda$ mong social scientists, constructivism has long reigned supreme in the study of ethnicity, nationality, and nationalism. Accordingly, scholars have highlighted the role of cultural framing and political choice in the definition of ethnic categories, their fluidity, and their flexible boundaries. Conversely, they have deemphasized the historical roots of ethnicity and depicted nations as the contested products of nationalist movements and political leaders and as (merely) "imagined communities" (Anderson 1991). Although constructivism encompasses a broad gamut of theories that differ in the malleability ascribed to ethnicity (Chandra 2012, 19-22, 139-49), recent authors have emphasized its susceptibility to change by highlighting manipulation by politicalelectoral entrepreneurs (Wilkinson 2012) and focusing on "identity in formation" (Laitin 1998), "ethnicity without groups" (Brubaker 2004), and "imagined noncommunities" characterized by "national indifference" (Zahra 2010).

New studies by historians, however, paint a different picture. Through an enormous amount of research, leading experts John Connelly and Helmut Walser Smith have unearthed the long-standing, solid roots of nationality. While also demonstrating the importance of cultural framing and political struggle over the aggregation of different ethnicities and especially over national boundaries, these massive books show how reasonably clear building blocks for these conflicts and decisions emerged and solidified over the course of centuries. Connelly's monumental canvas employs a broadly comparative perspective in analyzing the last 240 years of ethnic and national history across Eastern Europe, whereas Smith traces the emergence and transformation of nationhood in Central Europe over the last 500 years. With their impressive scope and depth and their innumerable interesting insights, these two books are of great relevance to students of ethnicity and nationalism in political science. To foster greater crossfertilization between our disciplines, this essay discusses their main implications for constructivist theorizing.

Above all, both books demonstrate the early origins, low viscosity, and great resilience of ethnicity and nationhood, which-although profoundly shaped and in Germany radically transformed by the later rise of nationalism-did not result from the political agency highlighted by constructivists. Billed as "the first major history of Germany in a generation," Smith's study documents that in Central Europe, German nationhood emerged long before nationalism, and it has persisted despite the terrible ravages and horrendous crimes caused by German ultranationalism under the Nazi regime. Similarly, Connelly highlights how East European peoples preserved themselves as collective units against the centralizing and homogenizing efforts of the empires governing the region, especially the Habsburgs. To prevent the erasure of their linguistic and cultural entity and historical legacies, they mobilized in defensive movements that then gave rise to nationalism. While the resulting quest for statehood spurred complex conflicts that eventually tore apart empires and created distinctive 
nations, these political units rested on ethnic collectivities that long preceded nationalism.

With their extensive time frames, these historical works thus show the long-standing, firm foundations of ethnicity and nationhood in a major part of Europe, thereby balancing political science accounts that emphasize recent political maneuvers and identity shifts. In these ways, historical research affirms the importance of cultural, structural, and historical roots of ethnicity, nationhood, and nationalism and corrects the overemphasis on political agency and ideational framing among constructivists. Our discipline benefits by learning from historians.

From close to 1,300 pages of narrative, this review essay extracts the insights of greatest relevance for political science. For this purpose, it first examines the arguments about the origins of ethnicity and nationhood, then focuses on the gradual rise of nationalism, discusses its tremendous power and explosive repercussions, and finally probes its persistence and transformation during the last few decades. It concludes by outlining a proposal for incorporating historical thinking more systematically into the political science analysis of ethnicity, nationality, and nationalism.

\section{Nationhood before Nationalism}

Going back half a millennium, Smith shows that the notion of Germany as a territorially bounded, culturally distinctive unit formed long before the political struggles of the nineteenth century that determined the specific political shape and international boundaries of this constantly contested entity. Although the rise and exacerbation of nationalism brought profound redefinitions of German nationhood, even the catastrophe caused by National Socialism did not lead to its erasure: "There was a Germany before, during, and after nationalism" (p. xi).

Smith documents the emergence of a sense of German nationhood through a fascinating analysis of maps, which from around 1500 onward showed a territorially conceived body surrounded by other distinct countries (pp. 7-9, 20-30, 41-44, 53-57, 119-21). This ethnic unit rested on linguistic commonalities enhanced by Luther's translation of the Bible and on distinctions from neighboring language families, such as a linguistic boundary in the west that remained virtually unchanged for more than 1,000 years. Moreover, the Holy Roman Empire of the German Nation provided a political-institutional bond that allowed for joint decision making and conflict resolution through its periodic diets and its judicial bodies. With a higher status than the surrounding kingdoms, the empire also embodied a historical mission that Germans found important through the ages.

The empire's weakening with the resolute expansion of France, and its growing internal fragmentation with the rise of Austrian-Prussian dualism, then created fear of Germany's disappearance in the eighteenth century, which stimulated an upwelling of popular patriotism (see chapter 4). Concerns about impending loss thus were important for broadening the commitment to German nationhood. This awakening coincided with important intellectual developments-namely, the inward turn to language and to the common people with their songs and folk tales that was spearheaded by Johann Gottfried Herder and his intellectual friends and deepened soon thereafter by the Romantic movement (chapter 5). By extolling German culture, these important currents affirmed a sense of nationhood and patriotic pride despite Germany's growing political weakness in the eighteenth century. Interestingly, with their emphasis on vernacular languages and popular authenticity, they also provided strong inspiration for East Europeans, as Connelly's book makes clear (pp. 84-94).

Just as Smith documents that the notion of German nationhood preceded nationalism by 300 years, so Connelly shows the solid foundations of ethnicity in Eastern Europe. Certainly, the conquest of indigenous kingdoms by culturally distinct empires created greater uncertainty about the scope of commonality, as evident in the long-standing debates over South Slav unity versus separate Croat, Serb, and other identities; moreover, the medieval migration of ethnic Germans and Jews into Slavic areas brought about a considerable linguistic mixture (pp. 43-49).

Nevertheless, language constituted collective units that were distinct from neighboring groupings, especially where a linguistic community was mostly surrounded by speakers of a different language family, as West Slavs were in Bohemia. Indeed, four major language families - Slav, German, Romance, and Finno-Ugric - existed side by side in fuzzy clusters in Eastern Europe (map on p. 34), creating divisions of great relevance to the population, which was mostly monolingual; Hungarian, for instance, is dreadfully difficult to learn.

Inside these language families, however, a dialect continuum (which ranged from Slovenia to Bulgaria, for instance) allowed for considerable flexibility and fluidity. What gave rise to internal distinctions that slowly hardened was religion; for instance, the hold of Western Christianity, Orthodox Christianity, and Islam over different parts of the South Slav area separated Croats from Serbs from Bosnians, respectively (pp. 35-42, 50-53).

Frequently overlapping with these religious differences, a political factor, namely historic statehood, reinforced these units. Interestingly, many of the later nation-states-for instance, Croatia, Serbia, Bulgaria, Hungary, Poland, and Czechia-had earlier incarnations as medieval kingdoms, many of which had enjoyed centuries of independence. Although these units were sooner or later amalgamated with or conquered by the rising Habsburg, Ottoman, and Romanov Empires (pp. 41-42, 49-53), their institutional roots solidified distinct ethnic groupings and provided crucial focal points for later nationalists demanding the reconstitution of separate states. 
Last but not least, the often-violent process through which the expanding empires had incorporated these medieval kingdoms constituted traumatic experiences that weighed on later generations, even centuries later. For instance, memories of the Battle of Kosovo (1389), which ushered in the Ottomans' coercive takeover of Serbia, were kept alive by the widespread popular performance of epic folk ballads, creating an intense commitment to nationhood among millions of Serbs for hundreds of years (pp. 39-42, 130-32, 142-51). Similarly, defeat at White Mountain in 1620, which led to the decimation of the Bohemian nobility and the imposition of the Catholic Counter-Reformation, caused a festering wound that undergirded Czech identity thereafter and fueled nationalist resentment in the nineteenth and twentieth centuries (pp. 56-58, 66, 73-74, 271, 301). And of course, Poland's carve-up by Austria, Prussia, and Russia in the late eighteenth century and the brutal suppression of desperate defensive uprisings fomented a strong sense of national identity and an eagerness for heroic reassertion through armed resistance and anti-imperial struggle (pp. 130-41).

These four factors-language, religion, historic statehood, and political trauma - and their complex intersection and frequent reinforcement underlay the solidity and resilience of ethnicity and nationhood in Eastern Europe. As Smith demonstrates for Germany, in that region there were distinctive ethnic units and protonations long before the rise of nationalism as well. Smith (pp. xi-xii) and Connelly (pp. 20-24, 788-90) argue, albeit often in a more discreet way than political scientists would do (Smith, p. 479, n2; Connelly, pp. 814-15, n18$22,24,27)$, that these historical findings clearly diverge from the constructivist emphasis on fluidity and manipulability. Although they were certainly shaped by political debates and conflicts, nations in large parts of Europe had long-lasting firm roots: these solid structures constrained and guided political agency. Past legacies had a stronger and longer-lasting impact than many constructivists claim, creating building blocks for later nationalist movements and limiting the maneuvering room of political leaders and identity entrepreneurs.

\section{The Rise and Irresistible Advance of Nationalism}

Both historians emphasize the distinctive origins of nationalism in Central and Eastern Europe, which-by contrast to Western Europe-emerged from the experience or prospect of loss and therefore became especially fierce. In Germany, the missionary expansionism of France's revolutionary nationalism inflicted a crushing defeat on Prussia in 1806. This shock stimulated a countermobilization that repelled Napoleon in 1813 and gave rise to a powerful nationalism defined by the defensive struggle against the "arch-enemy" in the West; yet it also entailed imposition in the East, where Prussia ruled over many Polish speakers (Smith, chapter 6).

Napoleon's destruction of the Holy Roman Empire turned German statehood into a burning question (Smith, chapter 7): How could a unified nation-state be created out of numerous independent polities? AustrianPrussian dualism brought a further complication, which was only resolved through war in the 1860s (chapter 8). Because the German Empire was founded under Prussian leadership, it excluded many millions of German speakers living under Habsburg rule, whose minority status instilled fear and prompted a particularly resentful nationalism, a precursor of Hitler's National Socialism (Connelly, chapter 9).

The German Empire, in turn, sought to compensate for its belated formation through particularly aggressive nation-building, which entailed acrimonious conflicts with the Catholic Church, Polish speakers in the east, and the rising socialist labor movement. Because these crucial developments have been analyzed by a voluminous literature, including Smith's earlier work, he outlines only their main contours; important issues, such as the difficult debate over a kleindeutsch (i.e., Prussian-led) versus großdeutsch (Austrian-led) unification, which centered on the inclusion of Austria's German speakers, are mentioned only briefly. Instead, Smith with his general focus on cultural and intellectual issues examines how the Bismarck Empire symbolized its identity through a variety of monuments (chapter 9).

While its birth from military defeat made German nationalism particularly martial and aggressive, in Eastern Europe the fear of loss reached even deeper and had more profound repercussions. As Connelly emphasizes, whereas countries in Western and Central Europe feared the capture of territory, a limited loss, in Eastern Europe the very survival of long-standing ethnic groupings was at stake (pp. 8, 22-25, 69-78, 130-53, 788-99). Slavic speakers across the region dreaded the threat of disappearance. After all, many Slavic tribes had assimilated into German culture in preceding centuries, leaving little trace; throughout Eastern Europe, most educated Slavs used German as their main language, often without knowing the ethnic vernacular at all; and Poland, the region's last Slavic state, had in the late eighteenth century been divided and swallowed up by neighboring empires. Thus, the very persistence of old ethnicities seemed at risk-a threat that, despite France's sustained westward expansion since the seventeenth century, even Germans did not fear.

One of Connelly's main arguments is that this danger of elimination and disappearance, especially self-dissolution through assimilation, drove East European nationalism and gave it a particularly fear-driven edge and intensity. These fears were activated and turned into an ever more potent political force when Habsburg rulers sought to forge greater unity in their highly heterogeneous empire 
by promoting the German language for administration and higher education (pp. 62, 67-69, 74-76). These homogenizing moves provoked a defensive reaction to preserve and upgrade the local vernaculars, which was most energetic in Bohemia. Ethnic Czechs who had been raised as fluent German speakers now began (!) to learn Czech (pp. 69-74, 88-96, 103, 123-24). This assertion of Slavic identity ran counter to the incentives for assimilation into the higher-status German-speaking society of Prague, contradicting Laitin's (1998) constructivist reasoning. Efforts to boost the economic standing of Czechs and achieve political influence and autonomy soon followed, giving rise to an increasingly contentious nationalism (pp. 169-72, 241-54, 337-47).

A similar reaction occurred in Hungary, where the powerful nobility rejected Habsburg unification efforts and instead started to pursue an independent nationbuilding project of their own. These ever more forceful moves toward Magyarization provoked defensive nationalism among the majority of other ethnic groupings in the realm, especially Croats in the southwest, Serbs in the south, Romanians in the southeast, and Slovaks in the north (pp. 75-78, 99-101, 108-11, 116-18). In all these cases, ethnic communities with deep historical roots sought to prevent their erasure; activists therefore formed nationalist movements, which gained popular support and developed growing militancy over the course of the nineteenth century.

\section{The Tremendous Power of Nationalism}

Both Smith and Connelly demonstrate that, born from the experience or prospect of loss, nationalism had tremendous, sometimes explosive, power in Central and East European history, contrary to authors who highlight "national indifference" (Zahra 2010; cf. Brubaker 2004, 20-27). In the Habsburg Empire, this force erupted first in the revolutions of 1848 , which temporarily weakened the center in Vienna and thus allowed nationalist movements to assert their demands (Connelly, chapter 6). But given the close proximity and partial intermixing of ethnicities and the status superiority and long-standing domination of some groupings over others, this sudden interest articulation quickly exploded into conflict. The cruelest fighting occurred in Hungary, whose quest for autonomy from Austria prompted similar stirrings among Slavic and Romanian groupings under Magyar domination. As atrocities proliferated and Europe suffered its first experience with ethnic cleansing (pp. 167-68, 181-86), the clever Habsburgs exploited these ethnic divisions to reimpose their command over Hungary.

This success, in turn, induced the weakening dynasty to assume the role of interethnic mediator and peace guarantor in the ever more precarious effort to manage the intensifying assertion of nationalist demands during subsequent decades. After coping with several crises, such as the negotiations with Hungary in the 1860s (Connelly, chapter 7) and the threatening creation of ethnic states in the Balkans in 1878 (chapters 8 and 11), the tottering Habsburg Empire finally suffered a knockout blow in World War I, which opened the way for the re-creation of several ethnically defined states in 1919 (pp. 321-23, 331-40). Ironically and tragically, however, none of these new units constituted true nation-states: they all had to cope with ethnic minorities inside or irredentist conationals across the border or both (pp. 343-61). No wonder that continuing ethnic conflict in most countries undermined political liberalism and helped prompt the installation of elitist dictatorship (chapter 13). Thus, the special force of nationalism in Eastern Europe, historically fueled by the fear of absorption and therefore especially intense in its ethnic assertiveness, deeply shaped the region's political fate.

There may have been numerous people who were "nationally indifferent" (Zahra 2010) and who embodied "ethnicity without groups" by not taking sides (Brubaker 2004). But the indifferent do not make history. Activists, and the people they can mobilize, do, as Connelly shows throughout his comprehensive study. And once nationalists stirred up conflict, loss aversion quickly induced additional people to join the fray and gave rise to "modern hatreds" (Kaufman 2001; cf. Petersen 2002, 25-28, 62-68), which lingered and thus prepared the ground for further conflict. As historical trauma had done in the past, nationalist struggles constituted critical junctures, whose uncertain outcomes congealed into path-dependent developments propelled by selfreproducing or reactive sequences (Mahoney and Schensul 2006, 465-68). By documenting these processes and their lasting repercussions across Eastern Europe, Connelly provides an important counterpoint to constructivism's bolder claims.

While Connelly convincingly demonstrates the enormous force of ethnic nationalism, Smith traces its eventual metastasis into biological racism in Germany and its resulting transformation into a Europe-wide project of genocide. His book shows how the exacerbation of nationalism that motivated mass sacrifice for the fatherland in World War I then contributed to the rise and government takeover of exclusionary, racist nationalism in 1933, the ever-fiercer anti-Semitism of the National Socialist dictatorship (Smith, 346-57), and the large-scale atrocities, massacres, and systematic genocide of World War II and the Holocaust. While the discussion of the Weimar Republic suffers from an idiosyncratic focus on a few artists (pp. 313-20, 330-36), the in-depth analysis of the Hitler regime's extermination campaigns-designed to create room for the imposition of a German warrior and slaveholder state across Poland and Russia - is outstanding in its thoroughness, clarity, and empirical documentation (pp. 298-306, 358-402). 
By contrast to Germany, fascism with its fanatical ultranationalism found only limited support in Eastern Europe, as Connelly demonstrates. Radical-right mass movements emerged only in Hungary and Romania, where the long-standing elite neglect of the peasant masses created space for extremist mobilization. Authoritarian regimes suppressed these bottom-up challenges, however (Connelly, chapter 14), and helped prevent fascism from getting a strong foothold elsewhere (chapter 15). Despite his temporary European hegemony, even Hitler rarely promoted the installation of fascist regimes in Eastern Europe; to advance Germany's economic and strategic interests, he preferred dealing with dictatorships sustained by conservative establishment sectors, rather than inexperienced, unpredictable charismatic leaders (Weyland 2021, chapters 7-8).

Although fascism did not take hold in Eastern Europe, the massive destruction wrought by German Nazism through World War II and the Holocaust (Connelly, chapters 16-17), which then provoked the expulsion of millions of ethnic Germans from across the region, brutally homogenized East European states by eliminating the two groupings that had immigrated during the Middle Ages (see the earlier discussion). Despite the gradual imposition of communist rule and Soviet hegemony (chapters 18-19), nationalism therefore continued to shape East European politics profoundly. Certainly, open defiance succeeded only in Yugoslavia, which steered an independent course from 1948 onward (pp. 563-66); other ambitious reform movements suffered forceful suppression, especially in Hungary in 1956 (chapter 20) and in Czechoslovakia in 1968 (chapter 22). But after Stalin's death, in particular, communist regimes across Eastern Europe felt compelled to accommodate nationalism, especially in Poland with its firmly rooted, influential Catholic Church and in Romania, where nationalistic communism incorporated even some strands of interwar fascism (chapter 21). The resilience of nationalism under a theoretically universalistic communism, whose class approach highlighted a very different sociopolitical cleavage, was remarkable.

Communism's downfall (chapters 24-25) then liberated national feelings and nationalist forces and brought about not only German reunification but also the quick breakup of the ethnically most heterogeneous countries through Czechoslovakia's peaceful "velvet divorce" (pp. 773-75) and Yugoslavia's violent implosion (chapter 26); that such a brutal conflict could erupt in Europe, despite the deterrent effects of World War II, reveals the persistent potency of ethnic nationalism. The two countries' failure to forge unified states, both during the interwar years and again under communism, demonstrates the limits of political agency. Intense nation-building efforts, spearheaded by unusually skillful leaders such as Czechoslovakia’s Tomáš Masaryk (pp. 299-306, 344-47, 411-15) and Yugoslavia's Josip Tito (pp. 455-59,
515, 745-47), foundered on the long-standing roots of separate ethnic groupings (especially Croat vs. Serb and Slovak vs. Czech). National identities had much lower plasticity than important currents of constructivism assume.

Eastern Europe's urge to join the European Union and thus benefit from Western prosperity helped strengthen postcommunist democracies and tame nationalism during the 1990s and early 2000s (pp. 776-84). But discontent with the social fallout of drastic market reforms and disenchantment with unaccountable politicians and their patronage-hungry parties soon spread and allowed for the rise of populism and the resurgence of nationalism, most clearly in Hungary, which continues to bemoan its postWorld War I mutilation (chapter 27).

\section{Nationhood after Nationalism}

Whereas in Eastern Europe, the cataclysm of World War II and four decades of imposed communism did not erase nationalism, in Germany-the country unleashing the most destructive war in human history and perpetrating unspeakable atrocities and crimes - the total defeat of 1945 prompted a fundamental rethinking that, however haltingly and imperfectly, redefined nationhood after the paroxysm of racist nationalism. As Smith highlights in the fifth part of his book, popular support for the Hitler regime faded only gradually, and facing the crimes committed in the German name, including the Holocaust, proved difficult. But from the 1970s onward, the effort to confront the past gathered steam and produced a new sense of nationhood centered on contrition, compassion, and pacifism (pp. 446-51, 457-65), as evident in Germany's comparatively generous admission of refugees in 2015-16. Although this humanitarian decision caused an ugly nationalist backlash fomented and exploited by the "Alternative for Germany," Smith correctly concludes that this relapse has found only minority support (pp. 46570). Thus, the complicated process of reconceiving the German nation and coping with the catastrophic experiences and legacies of ultranationalist racism has borne considerable fruit. As there was a German nation long before nationalism, it has survived the nationalist age as well. Analyzing this persistence and resilience despite the dramatic rise and fall of various projects of construction, destruction, and reconstruction is the fundamental contribution of Smith's fair-minded book.

\section{Conclusion}

With their wealth of findings and insights, these important books give political scientists ample food for thought. Their basic message highlights the historical roots and relative firmness of ethnicity and the enormous power and resilience of nationalism. With these arguments, Connelly and Smith balance the tendency among constructivists to stress the fluidity and malleability of ethnic identities and 
their manipulability by political leaders. Although both authors clearly confirm constructivism's fundamental insight that ethnic identities are not given and fixed, they also show that activists face strong incentives both to mobilize people along preexisting lines of difference, such as long-standing language or religious borders, and to invoke older loyalties, such as the legacies of earlier statehood. Rather than creating collective units at will, political leaders take advantage of historically evolved structures, which therefore shape political mobilization.

Moreover, to have major political effects, activists need not mobilize groupings comprehensively. A critical mass of nationalists can profoundly influence a country's fate even when many people remain "nationally indifferent" (Zahra 2010). Thus, even ethnic groupings with fuzzy edges (cf. Brubaker 2004) can have important political repercussions.

Connelly and Smith document these crucial points by showing how thoroughly Central and Eastern European politics was molded over the last 250 years by longstanding ethnic groupings, by activists' mobilization of nationalism, and by the incredibly powerful constructive and destructive impulses arising from this spreading movement. Ambitious, comprehensive ideologies such as communism and fascism came and went (Connelly, 792-94), political regimes frequently changed, but nationalism has shown great staying power.

These historical studies and their divergence from important currents of constructivism draw attention to a noteworthy gap in political science theorizing. The study of ethnicity and nationalism has drawn scholars from a great variety of paradigms and approaches, ranging from essentialism to constructivism and rational choice (Chandra 2012; Coakley 2018; Varshney 2007). Surprisingly, however, despite some notable exceptions (e.g., Brubaker 1992; Marx 2003), historical institutionalism has no marked presence. But this paradigm's attention to long stretches of continuity and path dependence and its fundamental emphasis on power and conflict seem especially well suited for elucidating these topics. Perhaps the new work of historians, which confirms the early roots, solid persistence, and remarkable resilience of ethnicity and nationhood, can encourage historical institutionalists finally to design their own distinctive, systematic approach. Indeed, the tremendous impact of historical traumata, ranging from the Battle of White Mountain in 1620 to Napoleon's defeat of Prussia in 1806 and the catastrophic (self-)destruction of German nationalism in 1945, constitute critical junctures that put nationhood and nationalism on new trajectories. As Connelly and Smith highlight, these shocks had enormous repercussions and left lasting legacies. Therefore, the powerful impact of loss aversion on the human mind, one of the fundamental insights of cognitive psychology (cf. Weyland 2021, chapter 2), could serve as a micro-foundation for such a historical-institutionalist approach.

More generally, this review essay suggests the usefulness of looking beyond our disciplinary boundaries and paying special attention to major works by historians. Political scientists can learn a great deal from their thorough research, careful process tracing, and contextualized comparisons, which are attentive to timing and sequences. Although it takes some time to dig through thick tomes of narratives, the reward is much greater depth of understanding. Historians, in turn, can learn from political science, for instance in the systematic use of concepts. As an example, both Smith (p. 227) and Connelly (pp. 22-23, 157, 178, 704, 720, 740) use the term "democratic" for movements such as the revolutionaries of 1848 or reformist Mikhail Gorbachev, although "liberal(ization)" would be much more appropriate; after all, few revolutionaries demanded broad suffrage, and Gorbachev never submitted himself to a competitive election. Thus, greater academic exchange may benefit both disciplines.

\section{Acknowledgements}

I thank Amy Liu, James Mahoney, and Raúl Madrid for their helpful suggestions.

\section{References}

Anderson, Benedict. 1991. Imagined Communities, revised edition. London: Verso.

Brubaker, Rogers. 1992. Citizenship and Nationhood in France and Germany. Cambridge, MA: Harvard University Press.

Brubaker, Rogers. 2004. Ethnicity without Groups. Cambridge, MA: Harvard University Press.

Chandra, Kanchan. 2012. Constructivist Theories of Ethnic Politics. Oxford: Oxford University Press.

Coakley, John. 2018. "'Primordialism' in Nationalism Studies." Nations and Nationalism 24 (2): 327-47.

Kaufman, Stuart. 2001. Modern Hatreds. Ithaca: Cornell University Press.

Laitin, David. 1998. Identity in Formation. Ithaca: Cornell University Press.

Mahoney, James, and David Schensul. 2006. "Historical Context and Path Dependence." In Oxford Handbook of Contextual Political Analysis, eds. Robert Goodin and Charles Tilly, 454-71. Oxford: Oxford University Press.

Marx, Anthony. 2003. Faith in Nation. Oxford: Oxford University Press.

Petersen, Roger. 2002. Understanding Ethnic Violence. Cambridge: Cambridge University Press. 
Varshney, Ashutosh. 2007. "Ethnicity and Ethnic Conflict." In Oxford Handbook of Comparative Politics, eds. Carles Boix and Susan Stokes, 274-94. Oxford: Oxford University Press.

Weyland, Kurt. 2021. Assault on Democracy: Communism, Fascism, and Authoritarianism during the Interwar Years. Cambridge: Cambridge University Press.
Wilkinson, Steven. 2012. "A Constructivist Model of Ethnic Riots." In Constructivist Theories of Ethnic Politics, ed. Kanchan Chandra, 359-86. Oxford: Oxford University Press.

Zahra, Tara. 2010. "Imagined Noncommunities." Slavic Review 69 (1): 93-119. 